\title{
PENGALAMAN PIMPINAN RUANG DALAM MELAKUKAN SUPERVISI PELAKSANAAN PEMBERIAN CAIRAN INTRAVENA
}

\author{
Ana Zakiyah \\ Depertemen Keilmuan Dasar Keperawatan dan Keperawatan Dasar. STIKes Bina Sehat PPNI \\ Kabupaten Mojokerto Jalan Raya Jabon Km 06 Mojokerto \\ E-mail: ana_ppni@yahoo.com
}

\begin{abstract}
ABSTRAK
Perawat mempunyai tanggung jawab dalam mengelola pemberian cairan intravena,. Upaya yang dilakukan oleh pimpinan ruang untuk mengevaluasi pelaksanaan tindakan tersebut melalui kegiatan supervisi sehingga dapat menghasilkan pelayanan yang berkualitas. Penelitian ini bertujuan memperoleh gambaran arti dan makna supervisi pelaksanaan pemberian cairan intravena yang dilakukan oleh pimpinan ruang. Desain penelitian yang digunakan adalah metode fenomenologi deskriptif, pengumpulan data dengan FGD dan wawancara mendalam. Partisipan pada penelitian ini diambil secara purposive sampling dan analisa data menggunakan metode Collaizi. Hasil penelitian diidentifikasi 5 tema yaitu pemahaman pimpinan ruang tentang supervisi, mempertahankan kinerja, meningkatkan pengetahuan dan keterampilan, pimpinan ruang memberikan dukungan dan dorongan, supervisi yang kurang terstandar. Berdasarkan hasil penelitian yang diperoleh, pimpinan ruang perlu memahami, melaksanakan fungsi manajemen guna mendukung kelancaran pelayanan di ruang rawat inap yang menjadi tanggungjawabnya, khususnya pada kegiatan supervisi dapat dilakukan secara berjenjang dan berkesinambungan.
\end{abstract}

Kata kunci: pemberian cairan intravena, pimpinan ruang, supervisi

\section{ABSTRACT}

Nurses have a responsibility in managing the administration of intravenous fluids. The efforts made by head nurse to evaluate the implementation of such measures through supervision activities so as to provide a quality service. This study aims to describe of the meaning and significance supervision of the implementation of intravenous fluids carried by the head nurse. The study design used is descriptive phenomenology method, data collection and in-depth interviews with a Focus Group Discussion. Participants in this study were taken by purposive sampling, data analysis using methods Collaizi. The results of the study identified five themes, namely understanding the leadership of space on supervision, to maintain performance, improve knowledge and skills, the head nurse to provide support and encouragement, supervision is less standardized. Based on the research results obtained, a head nurse need to understand the space, carry out the functions of management in order to support a smooth service in the inpatient unit is its responsibility, especially in the supervision activities can be carried out in stages and continous.

Key words: head nurse, intravenous fluid administration, supervision

\section{Pendahuluan}

Keselamatan pasien merupakan salah satu indikator yang digunakan untuk menilai kualitas asuhan keperawatan (Hugest, R.G, 2008). Salah satu intervensi keperawatan yang diberikan adalah pemberian terapi cairan intravena. Perawat mempunyai tanggung jawab dalam mengelola pemberian cairan intravena yang terdiri atas identifikasi cairan intravena yang diberikan dengan benar, identifikasi peralatan yang digunakan, melakukan prosedur yang dibutuhkan untuk memulai pemberian, mengatur kecepatan tetesan, dan mempertahankan pemberian cairan intravena sesuai program yang telah ditetapkan oleh dokter yang bertanggung jawab (Potter \& Perry, 2006). Namun dalam pelaksanaannya masih banyak kesalahan yang dilakukan oleh perawat, kesalahan tersebut meliputi kesalahan dalam memilih cairan, kesalahan menghitung kecepatan tetesan cairan intravena, dan kesalahan dalam administrasi (Mousavi, Khalili \& Khavidaki, 2012).

Kesalahan pemberian terapi cairan intravena menyebabkan peningkatan biaya perawatan di rumah sakit, tidak terpenuhinya keseimbangan cairan, bahkan pada kasus yang kompleks dapat terjadi kecacatan dan kematian (Han, Coombes, \& Green, 2012). 
Oleh karena itu peningkatan pengetahuan dan keterampilan perawat tentang pemberian terapi cairan intravena sangat penting untuk mencegah kesalahan (Rooker \& Gorard, 2005). Rumah sakit sebagai penyedia pelayanan kesehatan harus selalu berupaya untuk mengevaluasi tindakan-tindakan keperawatan yang telah dilakukan agar proses keperawatan menjadi berkualitas.

Upaya yang dilakukan untuk meningkatkan kualitas asuhan keperawatan adalah melalui kegiatan supervisi oleh pimpinan ruang. Supervisi bertujuan untuk meningkatkan pengetahuan dan keterampilan perawat pelaksana dalam memberikan asuhan keperawatan pada pasien. Supervisi merupakan bagian dari fungsi pengarahan, dalam fungsi manajemen sebagai salah satu cara yang efektif untuk mencapai tujuan di suatu tatanan pelayanan di rumah sakit termasuk tatanan pelayanan keperawatan (Lynch et al, 2008).

Supervisi yang efektif tidak hanya mengawasi dan mengamati apakah seluruh staf keperawatan menjalankan tugas dengan sebaik-baiknya sesuai dengan instruksi atau standar yang ada, tetapi juga berusaha memfasilitasi atau memotivasi perawat pelaksana untuk meningkatkan profesionalisme (Rowe,A \& Haywood,J, 2007).

Supervisi yang dilakukan dengan baik akan meningkatkan motivasi dan kesadaran diri perawat yang pada akhirnya berdampak pada kualitas asuhan keperawatan (Hyrkas, 2002), tetapi dalam praktiknya kegiatan supervisi sering berjalan tidak optimal, beberapa orang mempersepsikan supervisi sebatas pengawasan yang dilakukan jika terjadi suatu yang tidak sesuai dengan ketentuan yang berlaku. Hal ini menimbulkan kecemasan pada staf atau perawat pelaksana yang pada akhirnya tujuan supervisi tidak tercapai (Arwani \& Supriyatno, 2005).

\section{Metode}

Penelitian ini menggunakan metode fenomenologi deskriptif, yaitu berfokus pada penemuan fakta mengenai suatu fenomena sosial yang ditekankan pada usaha untuk memahami perilaku manusia berdasarkan perspektif informan (Streubert \& Carpenter, 2003; Sugiyono, 2010). Penelitian ini dilakukan di RSUD Sidoarjo. Partisipan dalam penelitian ini ditentukan dengan tehnik purposif sampling dengan kriteria: 1) pimpinan ruang yang bertugas di intalasi rawat inap, 2) berpengalaman menjadi pimpinan ruang minimal 3 tahun, 3) bersedia menjadi partisipan, 4) mampu mengungkapkan pengalamannya dengan baik. Partisipan dalam penelitian ini sebanyak enam orang. Pengumpulan data melalui Focus Group Discussion (FGD) dan wawancara mendalam. Teknik yang digunakan dalam analisis data penelitian ini yaitu menggunakan langkah-langkah dari Colaizzi.

\section{Hasil}

Rata-rata usia partisipan adalah 40 tahun dengan usia termuda 35 tahun dan usia tertua 42 tahun. Jenis kelamin partisipan 1 (17 \%) laki-laki dan 5 (83\%) perempuan. Tingkat pendidikan partisipan D4 keperawatan 1 (17\%) dan S1 keperawatan 5 $(83 \%)$. Masa kerja partisipan rata-rata 16 tahun. Partisipan yang pernah mengikuti pelatihan supervisi 4 (67\%) dan belum pernah 2 (33\%).

Hasil penelitian ini menghasilkan 5 tema yang selanjutnya tema-tema tersebut dilanjutkan menjadi sub tema berdasarkan tujuan penelitian. Berdasarkan tujuan tersebut peneliti menjabarkan dalam tema yakni pemahaman pimpinan ruang tentang supervisi, mempertahankan kinerja perawat pelaksana, pimpinan ruang berusaha meningkatkan pengetahuan dan keterampilan, pimpinan ruang memberikan dukungan dan dorongan kepada perawat pelaksana, supervisi pimpinan ruang kurang terstandar.

\section{Pembahasan}

Pimpinan ruang memahami supervisi sebagai sarana evaluasi dan kontroling. Alasan dilakukan supervisi diantaranya adalah karena dokumentasi pemberian cairan intravena yang belum bagus, label yang terdapat pada kantung infus sering hilang, dan pemberian cairan yang tidak sesuai dengan jadual. Supervisi yang dilakukan sebagai sarana untuk mendiskusikan hal-hal baru yang lebih baik, dan supaya perawat pelaksana bekerja sesuai dengan standar.

Pitman (2011) menjelaskan bahwa supervisi sebagai suatu kegiatan yang digunakan untuk memfasilitasi refleksi yang lebih mendalam dari praktek yang sudah 
dilakukan, refleksi ini memungkinkan staf mencapai, mempertahankan dan kreatif dalam meningkatkan kualitas pemberian asuhan keperawatan melalui sarana pendukung yang ada, mempertahankan dan kreatif dalam meningkatkan kualitas pemberian asuhan keperawatan melalui sarana pendukung yang ada.

Supervisi memegang peran utama dalam mendukung pelayanan yang bermutu melalui jaminan kualitas, manajemen risiko dan manajemen kinerja. Supervisi juga telah terbukti memiliki dampak positif pada perawatan pasien dan sebaliknya. Supervisi dalam praktek profesi kesehatan telah diidentifikasi sebagai faktor penting dalam meningkatkan keselamatan pasien, supervisi yang tidak memadai dijadikan sebagai pemicu kegagalan dan kesalahan yang terjadi dalam layanan kesehatan (Kilminster \& Jolly, 2000).

Pimpinan ruang berupaya mempertahankan kinerja perawat pelaksana dengan menilai penerapan SOP, menciptakan keselamatan pasien, dan mendiskusikan solusi yang diambil untuk memecahkan permasalahan. Pitman (2011), Allen \& Armorel (2010) serta Brunero dan Panbury (2002), supervisi dilihat dari aspek normatif dihubungkan dengan kemampuan supervisor untuk mempertahankan kinerja staf yang baik dengan membuat suatu perencanaan, menciptakan keselamatan pasien, mempertahankan standar yang ada, memberikan kepercayaan pada staf sehingga hal tersebut dapat meningkatkan profesionalisme dan menciptakan kualitas pelayanan yang bermutu.

Sesuai dengan penelitian Kilminster \& Jolly (2000), supervisi memiliki dampak positif pada perawatan pasien, supervisi dalam praktek profesi kesehatan telah diidentifikasi sebagai faktor penting dalam meningkatkan keselamatan pasien. Sedangkan dalam hal membuat suatu penyelesaian masalah pimpinan ruang melibatkan perawat pelaksana dengan tujuan mengindari kesalahpahaman dan memunculkan perasaan diberdayakan serta difasilitasi untuk bertanggung jawab atas pekerjaannya dan keputusan-keputusan yang diambil (Allen \& Armorel, 2010; Pitman, 2011).

Pimpinan ruang juga menyatakan bahwa supervisi dapat meningkatkan pengetahuan dan keterampilan melalui proses pemberlajaran yang ditujukan pada perawat pelaksana dengan mengajari perawat pelaksana dan menjelaskan SOP pemberian cairan yang benar. Pitman (2011), Allen \& Armorel (2010) menyatakan pada aspek formatif, supervisi berfokus pada pengembangan pengetahuan dan keterampilan staf. Arwani dan Supriyanto (2005), supervisor diharapkan mampu memberikan pelatihan dan bimbingan bersifat edukatif melalui supervisi langsung dengan pendampingan pada saat perawat memberikan asuhan keperawatan secara mandiri. Supervisor dapat memberikan umpan balik dan masukan dalam rangka perbaikan dan perawat pelaksana tidak merasa bahwa kegiatan supervisi tersebut merupakan sebuah pengawasan tetapi lebih ke arah bimbingan. Supervisor dapat memberikan dukungan dan reinforcement untuk memperbaiki segala sesuatu yang masih tidak sesuai dengan standar (Hill, Z., \& Loma, B, 2010).

Sedangkan supervisi secara tidak langsung dilakukan dengan memeriksa dokumentasi pemberian cairan intravena. Kelemahan cara ini adalah memungkinkan adanya perbedaan persepsi antara supervisor dan staf perawat karena supervisor tidak melihat secara langsung kegiatan-kegiatan yang dilakukan (Arwani \& Supriyatno 2005). Dengan demikian dibutuhkan suatu kemampuan dari pimpinan ruang untuk memberikan pengarahan sehingga apa yang disampaikan ketika supervisi dapat dimengerti dan dipahami oleh staf atau pelaksana keperawatan. Hal tersebut didukung dengan hasil penelitian Frankel (2008), supervisi yang dilakukan dengan baik dapat memberikan dukungan pada perawat untuk mengimplementasikan teori yang didapat ketika memberikan asuhan keperawatan pada pasien.

Pimpinan ruang mengungkapkan untuk memberikan dukungan dan dorongan dilakukan dengan memberikan semangat pada perawat pelaksana, memberikan reward jika kinerjanya baik. Pimpinan ruang juga memperhatikan perbedaan karakter dan usia perawat pelaksana, sehingga pimpinan ruang mempunyai cara tersendiri untuk melakukan pendekatan yaitu pendekatan persuasif terutama untuk perawat yang sudah tua. Hasil penelitian Brunero, Scott \& Panbury, Jane 
Stein (2002) menunjukkan bahwa aspek restorative berfokus pada pemberian dukungan dan motivasi. Pemberian dukungan dan kesempatan untuk merefleksikan peran staf terhadap pekerjaan dapat mencegah persepsi negatif yang mempengaruhi mereka dan pekerjaannya.

Hal senada juga diungkapkan Pitman (2011), pemberian dukungan dalam hal ini akan dicapai dengan cara menciptakan lingkungan yang aman pada saat supervisi dimana kepercayaan dan kerahasiaan dibuat untuk memberikan kesempatan staf yang disupervisi mengekspresikan perasaan dan ide-ide yang berhubungan dengan pekerjaan. Dengan demikian dibutuhkan kemampuan dari pimpinan ruang untuk berinteraksi dan memberikan dukungan atau motivasi sehingga hal tersebut dapat menstimulasi perawat pelaksana dalam melaksanakan pemberian cairan intravena dengan baik.

Seorang pimpinan ruang yang efektif dapat memberikan pengarahan yang baik melalui kegiatan supervisi dan koordinasi. Slainte dan Sosialta (2004), serta Pitman (2011) menyatakan bahwa supervisi yang dilakukan secara berkesinambungan dapat meningkatkan profesionalisme dan pengembangan pribadi serta komitmen untuk belajar secara terus menerus. Penelitian yang dilakukan oleh Dawson (2005) juga menyatakan bahwa supervisi memberikan konstribusi bagi peningkatan kualitas pelayanan yang diberikan kepada pasien.

Hasil FGD menunjukkan bahwa partisipan mengungkapkan supervisi merupakan sarana evaluasi dan kontroling serta monitoring terhadap perawat pelaksana. Pitman (2011) Standar pelayanan berfungsi sebagai acuan perawat pelaksana dalam memberikan asuhan keperawatan sehingga dapat terwujud pelayanan yang bermutu. Hasil penelitian Kilminster \& Jolly (2000) menjelaskan tujuan yang paling penting dari supervisi adalah meningkatkan kualitas dari pelayanan. Supervisi memegang peran utama dalam mendukung pelayanan yang bermutu melalui jaminan kualitas, manajemen risiko dan manajemen kinerja. Dengan demikian dapat ditarik suatu kesimpulan bahwa supervisi merupakan suatu proses yang penting dalam pengembangan sumber daya manusia. Supervisi yang dilakukan secara berkesinambungan dapat meningkatkan pengetahuan dan keterampilan seseorang yang pada akhirnya berdampak pada peningkatan mutu asuhan keperawatan.

\section{Simpulan}

Supervisi pada pelaksanaan pemberian cairan intravena yang dilakukan secara berkesinambungan melalui kegiatan pengarahan, observasi dan bimbingan pada perawat pelaksana dapat meningkatkan pengetahuan dan keterampilan seseorang yang pada akhirnya dapat meningkatkan mutu asuhan keperawatan. Supervisi merupakan suatu proses yang penting dalam pengembangan sumber daya manusia, oleh karena itu pimpinan ruang perlu memiliki kemampuan dalam memimpin, memiliki teknik dan keterampilan dalam melakukan supervisi untuk meningkatkan kualitas supervisi sehingga tujuan supervisi akan tercapai. Pemahaman pimpinan ruang dalam melaksanakan fungsi manajemen dapat mendukung kelancaran pelayanan di ruang rawat inap yang menjadi tanggungjawabnya, khusus pada kegiatan supervisi dapat dilakukan secara berjenjang dan berkesinambingan sehingga tujuan supervisi dapat tercapai.

\section{Daftar Pustaka}

Allen, A., et al. (2010). Profesional/ clinical supervision handbook for allied health profesionals. Lanarkshire NHS Lanarkshire. Diperoleh 22 Februari 2012 dari http://wilderdom.com/theory/growthcha lanesupport.html

Arwani \& Supriyatno, H. (2005). Manajemen bangsal keperawatan. Jakarta: EGC

Brunero, Scott \& Panbury, Jane Stein (2002). The effectiveness of clinical supervision in an evidence based literatur review. Australian Journal of Advanced Nursing. Volume 25 Number 3

Frankel, A. (2008). Applying theory to practice through clinical supervision. This is an extended version of the article published in Nursing Times; 104: 30, 30-31.

Halpern, H., \& Mc Kimm, J. (2009). Supervision. British Journal of Hospital Medicine, April 2009, Vol 70, No 4. Diunduh 22 Februari 2012 
Hendrich, A., \& Chow, M. (2008). Maximizing the impact of nursing care quality: a closer look at the hospital work environment and the nurse's impact. The United States: The Center Health Design

Hill, Z., \& Loma, B. (2010). Supervision. innovations at scale for community access and lasting effects. London: Institute of Child Health University College. Diunduh 30 Maret 2012

Hugest, R.G. (2008). Patient safety and quality: an evidence-based handbook for nurses. Rockville, MD: AHRQ Publication No. 08-0043.: Agency for Healthcare Research and Quality

Hyrkas, K. (2002). Clinical supervision and quality care. Tampere: Faculty of Medicine of The University of Tampere. Diperoleh 14 Februari 2012

Kilminster, S.M., \& Jolly. (2000) Effective supervision in clinical practice settings: a literature review. Ireland: Blackwell Science Ltd. Medical Education; 34:827-840. Diunduh 22 Februari 2012

Lynch, L., et al. (2008). Clinical supervision for nursing. United Kingdom: Blackwell Publishing

Mrayyan. M.T.(2010). Reported, causes, and reporting of medication error in teaching hospital in jordan: comparative study. Faculty of Nursing , Hashemite University, Zarqa, Jordan. Diunduh 4 Januari 2012 dari http://www.contemporarynurse.com/ archivea/vol/41.

Mousavi, M., Khalili., \& Khavidaki. S. (2012). Error in fluid therapy in medical wards. International Journal of Clinical Pharmacy. http://www.ncbi.nlm.nih.gov/pubme d/22392405. Diunduh tanggal 2 April 2012

Pitman, S.(2011). Handbook for clinical supervision: nursing post graduate programmes. Dublin: Royal College of Surgeon Ireland. Diunduh tanggal 22 Februari 2012 dari http://creativecommons.org/licences/ by-nc-sa/1.0
Polit, D.F., \& Beck, C.T. (2010). Essensial of nursing. Wolters Kluwer Health: Lippincott Company

Rassol, H., \& Lind.J.E. (2000). Perception of addiction nurses toward clinical supervision: an exploratory study. Departemen of Addiction Behavior \& Psycologycal Medicine. St. George's Hospital London. Vol 12 no 1 pages

Rowe, A., \& Haywood, J.(2007). Providing effective supervision. England: Skill for care \& CWDC. Diperoleh 22 Februari 2012 dari http.www.skillsforcare.org.uk.

Sharma, Manoj. (2005). Using focus groups in community based rehabilitation. Asia Pacific Disability Rehabilitation Journal Vol. 16 No. 12005

Slainte, \& Soisalta, S. (2004). Cinical supervision for mental health nurses in northern ireland. Best practice guidelines. Castle Buildings Belvast. Departemen of Social Services and Public Savety. Diunduh 22 Februari 2012 dari http://www.dhsspsni.gov.uk

Streubert, H.J., \& Carpenter, D.R.(2002). Qualitative research in nursing. Philadelphia: Lippincoth Williams \& Wilkins

Winstanley,J \& White, E.(2011). Clinical supervision: models, measure, and best practice. Australia: Nurse Researcer Vol 10 Number 